Research in Transportation Business \& Management, Volume 10, April 2014, pp. 15-25

DOI: $10.1016 /$ j.rtbm.2014.05.004

\title{
Customer Experience - an analysis of the concept and its performance in airline brands
}

Calum Laming ${ }_{1}$ and Keith Mason ${ }^{2}$

1. Air New Zealand

2. Cranfield University

This paper investigates the application of the concept of customer experience to the airline industry and the extent to which airline brands are delivering customer experience. A review of literature shows that the concept of customer experience is not well understood and has had no clear and consistent definition. The purpose of customer experience was identified as to deliver satisfaction throughout the customer experience that, in turn, leads to brand loyalty and advocacy.

The customer experience concept was then applied to the airline industry. In order to measure its performance a study was undertaken using International Air Transport Association (IATA hereafter) data collected over a twelve-month period from a sample size of 18,567 passengers on fifteen major full-service airlines on Europe-Middle East-Asia routes.

The elements of the airline passenger journey most strongly related to overall satisfaction, loyalty and advocacy were, for most airlines, cabin features followed by crew (for satisfaction) and inflight food and drink (for loyalty and advocacy). The analysis did not identify strong effects from the impact of airline continent, individual airline and flight class. The relationships between the passengers' satisfaction ratings for specified elements of the journey and the overall satisfaction, loyalty and advocacy were not moderated by flight class. 


\section{Introduction on customer experience}

How a customer experiences a service clearly impacts on how that customer will feel about the service provider and how he/she behaves in the future. It is therefore, somewhat surprising that the concept of customer experience has not, until recently, been at the forefront of marketing theory and application. In industries where standardised product offerings have led to a degree of commoditisation (where products offered by competing companies are very similar, such as the airline industry), Pine and Gilmore (1998) suggests that companies need to provide "experiences" that lead to customer satisfaction. Experiential differentiation is one area that companies operating in commodity markets may achieve a brand space that is their own.

Academic research on customer experience is somewhat limited and the concept is still considered to be relatively in its infancy (Johnston and Kong, 2011; Gentile et al., 2007; Verhoef et al., 2009; Frow and Payne, 2007; Klaus and Maklan, 2007). Researchers historically did not consider it a separate construct (Verhoef et al., 2009), however, customer experience as a concept that is now being considered of fundamental importance (Shaw and Ivens, 2002; Temkin, 2008). Hitherto there has been no clear and consistent definition of customer experience (Garg et al., 2010; Bullock, 2009). This lends explanation as to why the concept is yet to be embraced by many organisations (Meyer and Schwager, 2007) with only a few companies leading the way (Smith and Wheeler, 2002).

Customer experience is a highly evolved view of the traditional concept of the 'purchase process' introduced by Patterson in 1965, which discussed the steps and interactions between company and individual before purchase. Instead these 'steps' have been developed into interactions which deliver experiences and provide reactions (Ryder, 2007; Temkin, 2008a). Customer experience may be defined as:

the physical and emotional experiences occurring through the interactions with the product and/or service offering of a brand from point of first direct, conscious contact, through the total journey to the post-consumption stage.

As such it is a separate construct from brand and an evolution from, the traditional marketing/product and service functions within organisations. The customer experience concept transcends simply offering consumers a product or service (Mascarenhas et al., 2006). Customer experience comprises of a series of interactions between the company employees and the customer, also called customer "touchpoints" (Meyer and Schwager, 2007). It is more than just a one-time transactional experience or simple linear journey (as discussed in Shaw and Ivens, 2002). Instead, the concept has been extended to envelop all interactions between customer and company, or consumer and brand, including pre- and post-consumption phases (Bilton, 2008; Verhoef et al., 2009; Garg et al., 2010; IBM, 2005, Kim et al., 2011; Meyer and Schwager, 2007, Pine and Gilmore, 1999; Johnston and Kong, 2011; Addis and Holbrook, 2001; Chordiant, 2008). It delivers both emotional and functional benefits to the consumer (Schuler et al., 2005).

The purpose of customer experience is to drive brand success by creating a brand-based customer experience which is differentiated from its competitors and for which consumers are willing to pay. By delivering total satisfaction in its execution, good customer experience delivers revenue, profitability and growth (Frow and Payne, 2007). Research has demonstrated (see, for example Temkin, 2008) that when customers are truly satisfied they become loyal to the brand. The ultimate aim of this journey is when loyal customers become advocates, willing to remain loyal to the brand through circumstances even of poor delivery and willing to both recommend and defend a brand to others (Shaw and Ivens, 2002; Schmitt, 2003).

There is no generally accepted method for measuring customer experience performance (Klaus and Maklan, 2007). The key indicator is customer satisfaction. However this is much more than one overall satisfaction score. Customer experience is predicated upon a series of steps along a journey, which each individual consumer undertakes with a brand. Thus an understanding of satisfaction at 
these distinct stages is necessary to develop and refine the experience over time (Smith and Wheeler, 2002, Meyer and Schwager, 2007, Bilton, 2008).

Although achieving the excellent customer experience at each touchpoint would be a key aim of all commercial airlines, Thompson (2006) argues that airlines are not achieving this. In cross-industry study he found that only $18 \%$ of passengers believed that airlines delivered an excellent customer experience. This translates into commercial losses. According to Heskett et al. (1997) in a study of British Airways they found a potential revenue loss of over f26 million through not delivering passengers' required customer experience. In order to deliver excellent customer experience, airlines must first fully understand their levels of passenger satisfaction throughout all stages of their customer experience.

It is not clear whether many airlines simply do not apply the concept of customer experience or do not understand the passenger satisfaction levels across their entire customer journey. Meyer and Schwager (2007) suggest that whilst many Chief Executive Officers (CEOs) recognise the importance of customer experiences, companies have invested heavily in Customer Relationship Management and airlines are a particular case in point with their powerful and complex loyalty schemes - in the past and are unwilling to invest into what is considered a relatively new and poorly understood concept (Verhoef et al., 2009).

\section{Customer experience in airline industry}

The growing perception of the importance and relevance of customer experience to the airline industry is demonstrated by new structures adopted by some airlines, such as Etihad Airways in 2011. Etihad's new structure saw the introduction of a Customer Experience department, the focus being on its passengers, as distinct from traditional product and service development. According to the CEO (Hogan, 2011) customer experience is a key strategy for achieving differentiation and for delivering total customer satisfaction, which generates loyalty and advocacy and delivers business growth. Introducing a Customer Experience function is seen as a key cornerstone of success for future profitability and growth for airlines (Baumgartner, 2011, Shave, 2011).

Managing various complex elements of the airline customer experience is a distinct challenge for airlines, made more challenging as many of the staff (for example airports, security, customs and immigration) are outside an airline's direct control and complicate the customer journey (Nigam, 2008; Verhoef et al., 2009). Smith and Wheeler (2002) suggest however this is one of the key elements in achieving great customer experience within airlines, citing the examples of Virgin Atlantic and Southwest, who embed their staff within the customer experience, and empower their team to deliver.

Driver (1999) argues that achieving differentiation in the airline industry is difficult, with essentially common environments, virtually identical aircraft and similar airports, as they are not in control of some of the crucial elements of their customer journey. Successful examples of achieving differentiation through elements of the customer experience are detailed in literature, however, these are limited to specific examples or short case studies, and not around customer experience as a construct (see Table 1). 
Table 1: Overview of Airline Examples in Customer Experience Literature

\begin{tabular}{|c|c|c|}
\hline Source & Airline & Example \\
\hline \multirow{6}{*}{$\begin{array}{l}\text { Smith and } \\
\text { Wheeler } \\
(2002)\end{array}$} & Southwest & $\begin{array}{l}\text { Southwest Airlines adapted the model of developing a customer } \\
\text { experience. It was the first airline to do so. }\end{array}$ \\
\hline & easyJet & $\begin{array}{l}\text { Includes a quote from founder Stelios Haji-loannou supporting } \\
\text { the concept of 'branding the experience', how the customer } \\
\text { experience of the airline was developed before the brand, and } \\
\text { the what the brand became after its adoption. }\end{array}$ \\
\hline & Virgin & Cites an example of brand and advocacy, when 10 people out of \\
\hline & Atlantic & $\begin{array}{l}300 \text { at a conference admitted to being brand advocates without } \\
\text { ever having flown the airline. }\end{array}$ \\
\hline & British & Quotes an example of how the airline restructured their Cabin \\
\hline & Airways & $\begin{array}{l}\text { Crew recruitment by using operational cabin crew rather than HR } \\
\text { professionals, which resulted in recruiting staff that better } \\
\text { understood the airline's brand values and were more in tune to } \\
\text { deliver the desired customer experience. }\end{array}$ \\
\hline $\begin{array}{l}\text { Kamaladevi } \\
\text { (2010) }\end{array}$ & Kingfisher & $\begin{array}{l}\text { The paper identifies the differentiation achieved by this airline's } \\
\text { by it's offering: seatback IFE at every seat and enhanced seating, } \\
\text { inflight product and service benefits and doorstep ticket delivery. }\end{array}$ \\
\hline \multirow[t]{2}{*}{$\begin{array}{l}\text { Schuler et } \\
\text { al. (2005) }\end{array}$} & Finnair & $\begin{array}{l}\text { The paper identifies the airline's focus on understanding } \\
\text { customer needs across all touchpoints to create differentiation, } \\
\text { with the aim of stemming the threat of competitors. }\end{array}$ \\
\hline & JetBlue & $\begin{array}{l}\text { The paper highlights how JetBlue's rapid growth threatened its } \\
\text { customer experience, and how a focus on the check-in } \\
\text { interaction with its customers maintained differentiation. }\end{array}$ \\
\hline $\begin{array}{l}\text { Temkin } \\
(2008)\end{array}$ & United & $\begin{array}{l}\text { United is identified as one of } 25 \text { firms who discussed their } \\
\text { customer experience efforts and contributed to the survey upon } \\
\text { which the research in this paper is based. }\end{array}$ \\
\hline $\begin{array}{l}\text { Thompson } \\
(2006)\end{array}$ & SAS & $\begin{array}{l}\text { This paper mentions of the turnaround of the airline through the } \\
\text { introduction of the 'Moments of Truth' concept by CEO Jan } \\
\text { Carlzon. }\end{array}$ \\
\hline \multirow[t]{3}{*}{$\begin{array}{l}\text { Shaw and } \\
\text { Ivens (2002) }\end{array}$} & $\begin{array}{l}\text { Virgin } \\
\text { Atlantic }\end{array}$ & $\begin{array}{l}\text { This paper includes a quote from a manager on how Virgin } \\
\text { Atlantic delivers experience differentiation through product and } \\
\text { service. }\end{array}$ \\
\hline & & $\begin{array}{l}\text { Also a managerial quote on the incorporation of the brand into } \\
\text { the recruitment process to find people who are a natural fit to } \\
\text { deliver their brand's customer experience. }\end{array}$ \\
\hline & & $\begin{array}{l}\text { And finally, the paper includes a management quote on how } \\
\text { customer experience leadership is exemplified from the very top } \\
\text { by the owner, Richard Branson. }\end{array}$ \\
\hline \multirow[t]{2}{*}{$\begin{array}{l}\text { Springer et } \\
\text { al. (2011) }\end{array}$} & JetBlue & $\begin{array}{l}\text { JetBlue is identified as achieving strong levels of advocacy by } \\
\text { their customers, in their survey they had an "Net Promoter } \\
\text { Score" (NPS) of over } 60 \% \text { and CAGR of } 17.9 \% \text { against the laggard } \\
\text { in their industry with an NPS of more than }-10 \% \text { and CAGR of - } \\
3.3 \% \text {. }\end{array}$ \\
\hline & KLM & $\begin{array}{l}\text { The launch of the 'Make It Speedy' initiative, based on insights of } \\
\text { their loyal customers, allowed the airline to realise a potential } \\
€ 100 \text { million contribution by turning these customers into } \\
\text { advocates. }\end{array}$ \\
\hline $\begin{array}{l}\text { Stewart } \\
(1997)\end{array}$ & Southwest & $\begin{array}{l}\text { The paper explains how Southwest Airlines delivers a strong } \\
\text { customer experience through its commitment to their brand and } \\
\text { core offering: cheap, fast, no-frills travel. }\end{array}$ \\
\hline
\end{tabular}

Source: compiled by authors

More widespread in the literature is research that focuses on the quality of service in the airline industry, particularly the application of the SERVQUAL model to the industry (see for example, 
Ostrowski et al. (1993), Zins (2001), Gilbert and Wong (2003), Park et al. (2004), Chen and Chang (2005), Martín et al. (2008), Rhoades and Waguespack (2008), Nadiri et al. (2008), Strombeck and Wakefield (2008), Liou et al. (2011) among many others). Service quality (SERVQUAL) is a perceptive measurement of how an experience matches an individual's expectation. Whilst SERVQUAL is good for examining the gap between expectation and service deliver, it is not an effective means of scoring customer experience, which requires a measurement of a customer's satisfaction throughout each individual aspect of their journey.

In order to measure customer experience in terms of its major purpose - to deliver customer satisfaction to drive loyalty and advocacy (Kalamadevi, 2010; Thompson, 2006; Frow and Payne, 2007; Johnston and Kong, 2011; Thompson and Davies, 2008) - an individual customer satisfaction rating is therefore required at all the touchpoints structured along an airline journey; from booking, to checkin, lounge, boarding, in-flight, transfer, baggage, leaving the airport, etc. The individual elements of the journey can then be measured to ascertain which are the ones which are more closely correlated to driving satisfaction, loyalty and advocacy: critical for delivering customer experience (Strombeck and Wakefield, 2008). Therefore it is desirable to have customer satisfaction data throughout their experience, however, such data is hard to come by for academic researchers in this field.

Headley and Bowen (1997) detail the difficulty in obtaining research around customer satisfaction in the airline industry. Waguespack et al. (2007) give an overview of the data released by regulatory bodies but explain its limitations in terms of measuring customer experience. The measures reported by the US Department of Transportation and used for the annual 'Airline Quality Ratings' (available at http://www.airlineinfo.com) are limited to measuring on time performance, denied boardings, mishandled baggage and customer complaints. However customer experience data does exist in the airline industry produced either by the airlines themselves or by IATA, such as the Airs@t Benchmarking survey, which are either prohibitively expensive for academic purposes, or are confidential and not published (Waguespack et al., 2007; Headley and Bowen, 1997).

\section{Research objectives}

Customer satisfaction data structured around the airline passenger journey is required to measure customer experience. From such data, analysis can be conducted to give an overview of customer experience performance across the elements of the journey.

The reason there has been limited numbers of published studies of airline customer experience have to date is a consequence of not having access to consistent, regular airline passenger satisfaction data which (a) is reported periodically; (b) covers the entire passenger journey; (c) is on an international scale and (d) is collated for a number of airlines. Such data is something that is both discussed and desired by researchers (Ostrowski et al., 2003; Waguespack et al., 2007; Headley and Bowen, 1997).

The purpose of this study aims to provide insight into airline customer satisfaction levels by analysis of a large-scale survey of airline passengers. Data from 18,567 passengers from 15 airlines were analysed. Access to this database of passenger information has been secured by the authors and made available to the researchers, under an agreement where the performance of individual airlines was not identified. Whilst this limits the details that can be me made about specific airlines, findings about airline customer satisfaction levels and the factors that affect these are not limited.

The performance of customer experience in today's airline brands, the satisfaction ratings of airline passengers were studied using data derived from an IATA survey of passengers travelling on EuropeAsia routes with fifteen full-service airlines based in Europe, Asia and the Middle East.

Airs@t is an independent, global, in-depth survey produced by IATA of detailed customer satisfaction ratings covering the complete customer experience: all travel aspects and every touchpoint - preflight, inflight and post-flight elements of the airline passenger journey are measured. Covering twenty-three major world airlines, twenty-seven of the world's largest airports and over 40,000 passengers per year, the data is gathered for all cabins flying on four categories of routes: long-haul Europe-Middle East/Asia; long-haul transatlantic, long-haul transpacific and short-haul intra-European 
flights. It gives details on more than 50 measured attributes, which are broken down further (IATA, 2011). IATA is the association of around $90 \%$ of the world's airlines. As an industry association, it conducts and produces statistics for the use by their members, and also publishes various reports on the state of the industry, forecasts of future industry performance (e.g. WATS, 2013) and some surveys of passengers (CATS, 2009). The passengers' responses collected in this study were ex post facto, and could not be manipulated or controlled by the researchers.

This paper sets out to examine the impact of passenger satisfaction levels for specific parts of their journey; the various touchpoints passengers have experience during their interaction with an airline. It is expected that the class of travel a passenger chooses will affect his or her experience, as will the individual airline brand they fly with. The levels of passenger experience may also differ between airlines located in different continents. The research sets out to discover whether customer experience received on European airlines is better or worse than those received on Asian, or Middle Eastern airlines. The value to an airline of a satisfied customer is hypothesised to be increased loyalty to that airline, and increased likelihood that that passenger will become an advocate for the airline. Therefore, it is expected that loyalty to an airline and also the likelihood that a passenger will be an advocate for the airline if their experience with the airline is good. Consequently, the following five hypotheses were tested:

- $\mathrm{H}_{0} 1$ : The passengers' satisfaction ratings are related to the continent from which the airline flown is based, the individual airline, and the class of the flight.

- $\mathrm{H}_{0} 2$ : At least one of the passengers' satisfaction ratings for specified elements of their journey is strongly related to their overall satisfaction rating for the airline.

- $\mathrm{H}_{0} 3$ At least one of the passengers' satisfaction ratings for specified elements of their journey is strongly related to their loyalty to the airline

- $\mathrm{H}_{0} 4$ : At least one of the passengers' satisfaction ratings for specified elements of their journey is strongly related to their advocacy for the airline

- $\mathrm{H}_{0} 5$ : At least one of the relationships between the passenger's satisfaction ratings for specified elements of their journeys, and overall satisfaction, loyalty, or advocacy is moderated by their flight class.

\section{Methodology}

There is no clearly defined method of measuring customer experience (Klaus and Maklan, 2007) and therefore the methodology was adopted to study customer experience within the airline industry based on the following concepts: a study of customer satisfaction at the stages throughout the airline passenger journey, and analysis of the elements of the customer journey which most closely align to the purpose of customer satisfaction and its constituent measures of brand success - satisfaction, loyalty and advocacy. Here, emphasis was given to analysing the levels of passenger satisfaction with respect to their overall scorings of the constituent parts of the airline's customer journey: the carrier's website, reservations, check-in, airport lounge, boarding and departure, cabin and seat features, crews and pilots, IFE, inflight food and drink, and arrival.

Data were collected over one year, stratified into the third and fourth quarters of 2010 (July, August, September 2010 and October, November, December 2010 respectively) and the first and second quarters of 2011. Invitations to participate in the research were distributed to passengers of fifteen airlines at fifteen airports across Europe, Asia and the Middle East according to a sampling plan developed by IATA which was reflective in its proportions of the different carriers' actual networks. 18,567 survey responses were collected.

The survey instrument used to collect the data, known as the 'Airs@t' Survey, was an online questionnaire consisting of 43 questions administered by M1nd-set, a Swiss-based research agency. The target population consisted of passengers who had travelled on long-haul Europe-Asia routes with fifteen full-service airlines (coded to preserve their anonymity). Five of the airlines were based in Asia (coded AS1 to AS5), seven in Europe (coded EU1 to EU7) and three in the Middle East (coded 
ME1 to ME3). In addition to age, gender, nationality and class of travel questions, customer ratings for the following experiences in the service provision were recorded on a five point ordinal scale from $1=$ Poor to $5=$ Excellent. To assess any impact of delays on the their experience ratings, respondents were also asked to record whether their flight had been delayed $(1=>90 \mathrm{mins}, 2=61-90 \mathrm{~min}, 3=31$ $60 \mathrm{~min}, 4=15-20 \mathrm{~min}, 5=<15 \mathrm{~min}$ ).

\begin{tabular}{ll}
\hline Q 9 & Overall rating for reservation services \\
Q 10 & Overall rating for website services \\
Q 12 & Overall rating for check-in \\
Q 14 & Overall rating for lounge \\
Q 17 & Overall rating for boarding and departure \\
Q 18 & Overall rating for cabin features \\
Q 19 & Overall rating for seat features \\
Q 20 & Overall rating for crew and pilots \\
Q 21 & Overall rating for IFE \\
Q 22 & Overall rating for inflight food and drink \\
Q 23 & Overall rating for arrival \\
Q24V & Rating for perception of value for money \\
Q24A & Overall satisfaction rating of the airline \\
Q 25 & Comparison to expectations \\
Q 26 & Likelihood of using the same airline again (Loyalty) \\
Q 27 & Likelihood of recommending the airline to family, friends, colleagues, etc. \\
& (Advocacy) \\
\hline
\end{tabular}

The median and not the mean was selected as the most appropriate descriptive statistic to summarise the ordinal responses to each question (Agresti, 2007). As the scales for customer satisfaction used are ordinal, the intervals between each adjacent point on the 5-point scale may not be equal. Furthermore, it was unlikely that the responses would be normally distributed and more likely to be skewed, with the highest frequencies clumped at one or other end of the scale. Indeed, upon investigation of the dataset, it was established that the frequency distributions of the responses for all of the questions were not normally distributed. The highest frequencies were not at the centre, but tended to be clustered towards the higher end of the 5-point scales. The skewed distributions were reflected by consistently high median scores ranging from 3 to 5 . For an asymmetric or skewed frequency distribution, the mean tends to be a biased estimate of central tendency, whereas the median is not so sensitive to the skewness of the distribution (Agresti, 2007).

Kruskal-Wallis $\chi^{2}$ tests were conducted to test the null hypotheses $\left(\mathrm{H}_{0} 1-\right.$ to $\left.\mathrm{H}_{0} 4\right)$ that there were no significant differences between the median scores with respect to the continent of the airline and the flight class, and that at least one customer experience rating was related to overall satisfaction, loyalty and advocacy. The theoretical assumption of the Kruskal-Wallis test conducted in SPSS was that the scores were ranked in a logical sequence or order. The conventional decision rule applied in this study was to reject the null hypothesis if the probability ( $p$ value) of the result being due to random chance was less than $5 \%$, indicated by $p<0.05$ for the $\chi 2$ statistic (Agresti, 2007).

Spearman's Rho was used to assess the relationship between passenger ratings for individual journey elements and their overall satisfaction ratings. SPSS routinely computes the magnitude of a correlation coefficient and its corresponding probability ( $p$ value). The $p$ value determines whether or not the correlation coefficient is statistically significant, implying that its magnitude is greater than that expected by random chance. The conventional decision rule applied in this study was that the $p$ value must be less than 0.05 for the correlation coefficient to be statistically significant (Field, 2009). One of the difficulties involved in interpreting the results of correlation analysis is that it is much easier to obtain a statistically significant coefficient when the sample size is large then when the sample size is small. For example, at the 0.05 level of significance, with a sample size of $N=100$, Spearman's rho must be $\geq 0.197$ to be statistically significant; with a sample size of $N=1000$, 
Spearman's rho must be $\geq 0.062$ to be statistically significant. With very large sample sizes, statistically significant correlations may occur very easily just by random chance (Bowker and Randerson, 2007).

Consequently when the sample size is greater than 1000, as in this study, a correlation is often declared to be statistically significant at $p<0.05$, irrespective of whether or not there is a real association between the variables. Because of the large sample size $(N=18,567)$ used in this study, resulting in the possibility that most, if not all, of the correlation coefficients might by random chance be declared to be statistically significant at $p<0.05$, the $p$ values were not considered to be very important. The magnitudes of the correlation coefficients were interpreted subjectively, as defined in Table 2.

Table 2: Interpretation of correlation coefficient for large data set

\begin{tabular}{ll}
\hline Correlation coefficient & Interpretation \\
\hline$<.1$ & Very little or no correlation \\
\hline 0.11 to 0.3 & Very weak correlation \\
\hline 0.31 to 0.45 & Weak correlation \\
\hline 0.46 to 0.6 & Moderate correlation \\
\hline 0.6 to 0.75 & Strong correlation \\
\hline$>0.75$ & Very strong correlation \\
\hline
\end{tabular}

Source: Bowker and Randerson, 2007.

To test for moderation requires exploration of the covariance matrix, including a combination of regression analysis and analysis of variance, to probe for interactions between the slopes of linear regression lines and moderating variables. A simple graphical approach was used to explore moderation by flight class (to assess $\mathrm{H}_{0} 5$ ) following a method described by Bowker and Randerson (2007). Graphs were constructed consisting of two simple linear regression lines, one for the passengers who travelled in Business Class and the other for the passengers who travelled in Economy Class (rrelatively few passengers travelled in First Class and Special Economy Class, therefore these were not included in this analysis.). The two regression lines were used to compare visually the strengths and directions of the relationships between overall satisfaction, advocacy, or loyalty and the satisfaction ratings of Business and Economy Class passengers with respect to specific elements of their journey. If the two lines were clearly seen to be not parallel, diverging or crossed each other, then it was inferred that the flight class had a moderating effect, because the strength and/or direction of the relationship was different for Business Class passengers compared to Economy Class passengers. If the two linear regression lines were seen to be either parallel or approximately parallel, with the same or similar slopes then moderation was not supported.

\section{Results}

The total sample consisted of $N=18,567$ passengers. $73.8 \%$ were male. The distribution of respondents by age is shown in Figure 1 . More than half of the respondents $(n=10003,54.0 \%)$ were aged 35-54. The next most frequent age group was $26-34(n=3,432,18.5 \%)$ followed by $55-64(n=$ $3,307,17.8 \%)$. 


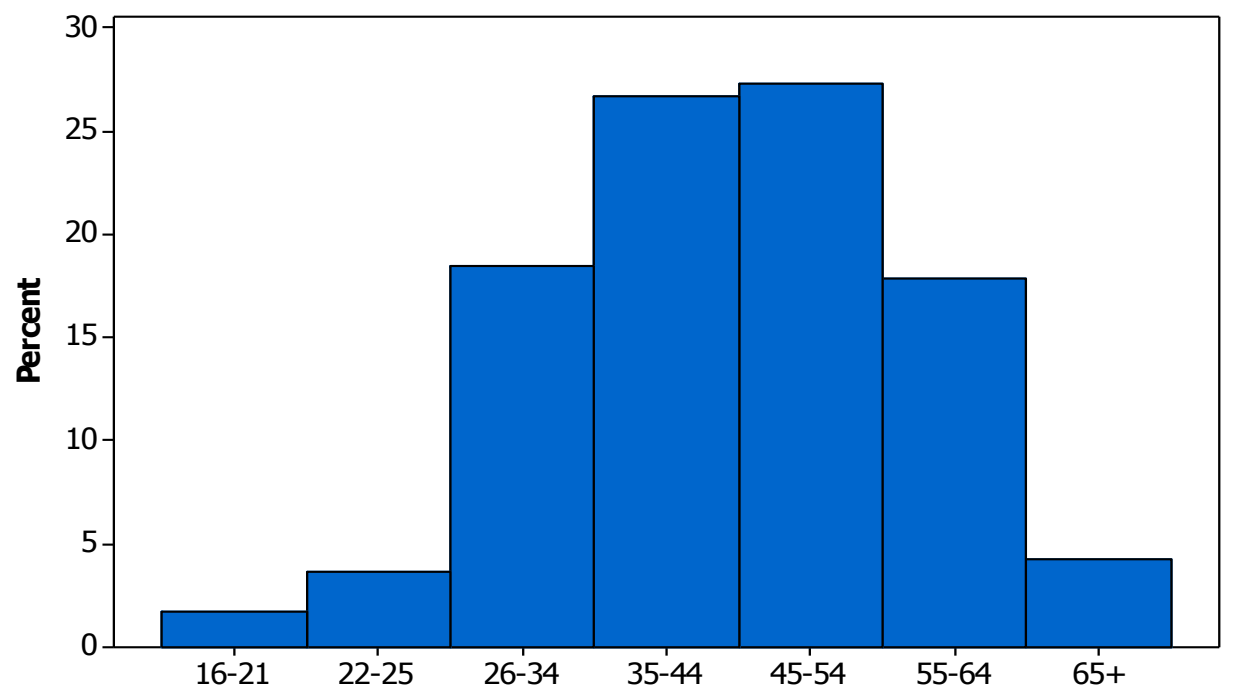

Figure 1: Frequency Distribution of Respondents by Age Group

Almost half of the passengers were selected from airlines based in Europe (see Table 3). About a third of the passengers were selected from airlines based in Asia, and a fifth of the passengers were selected from airlines based in the Middle East.

Table 3: Distribution of Responses by Home Continent of Airline

\begin{tabular}{lcl}
\hline Continent & Responses & Relative Frequency \\
\hline European airlines & 8,636 & $46.51 \%$ \\
Asia airlines & 6,211 & $33.45 \%$ \\
Middle East airlines & 3,720 & $20.04 \%$ \\
\hline Total & 18,567 & $100.0 \%$ \\
\hline
\end{tabular}

The majority (60.0\%) of the passengers travelled in Economy Class. About one third were in Business Class (33.3\%). Relatively few were in Premium Economy Class (4.4\%) and the smallest proportion travelled First Class (2.2\%).

Table 4: Frequency Distributions of Numerically-Coded Responses (1 to 5) to Questions concerning Passenger Satisfaction

\begin{tabular}{|c|c|c|c|c|c|c|c|c|}
\hline $\begin{array}{l}\text { Qu. } \\
\text { No. }\end{array}$ & $\begin{array}{l}\text { Overall } \\
\text { scoring } \\
\text { area }\end{array}$ & $\begin{array}{c}1 \\
\text { (Worst) }\end{array}$ & 2 & 3 & 4 & $\begin{array}{c}5 \\
\text { (Best) }\end{array}$ & $\begin{array}{c}\text { Valid } \\
\text { Responses }\end{array}$ & $\begin{array}{c}\text { Median } \\
\text { value }\end{array}$ \\
\hline 9 & $\begin{array}{l}\text { Reservation } \\
\text { services }\end{array}$ & $\begin{array}{c}15 \\
(1.6 \%)\end{array}$ & $\begin{array}{c}34 \\
(3.6 \%)\end{array}$ & $\begin{array}{c}171 \\
(18.1 \%)\end{array}$ & $\begin{array}{c}379 \\
(40.2 \%)\end{array}$ & $\begin{array}{c}344 \\
(36.5 \%)\end{array}$ & $\begin{array}{c}943 \\
(5.1 \%) \\
\end{array}$ & 4 \\
\hline 10 & $\begin{array}{l}\text { Website } \\
\text { services }\end{array}$ & $\begin{array}{c}229 \\
(1.5 \%) \\
\end{array}$ & $\begin{array}{c}1,245 \\
(8.0 \%)\end{array}$ & $\begin{array}{c}5,018 \\
(32.2 \%)\end{array}$ & $\begin{array}{c}6,437 \\
(41.4 \%)\end{array}$ & $\begin{array}{c}2,637 \\
(16.9 \%)\end{array}$ & $\begin{array}{c}15,566 \\
(83.8 \%) \\
\end{array}$ & 4 \\
\hline 12 & Check-in & $\begin{array}{c}243 \\
(1.3 \%)\end{array}$ & $\begin{array}{c}922 \\
(5.0 \%) \\
\end{array}$ & $\begin{array}{c}3,723 \\
(20.1 \%)\end{array}$ & $\begin{array}{c}7,405 \\
(40.0 \%)\end{array}$ & $\begin{array}{c}6,197 \\
(33.5 \%)\end{array}$ & $\begin{array}{c}18,490 \\
(99.6 \%) \\
\end{array}$ & 4 \\
\hline 14 & Lounge & $\begin{array}{c}268 \\
(3.8 \%) \\
\end{array}$ & $\begin{array}{c}1,154 \\
(16.4 \%)\end{array}$ & $\begin{array}{c}2,275 \\
(32.4 \%)\end{array}$ & $\begin{array}{c}2,231 \\
(31.8 \%)\end{array}$ & $\begin{array}{c}1,092 \\
(5.9 \%) \\
\end{array}$ & $\begin{array}{c}7,020 \\
(37.8 \%)\end{array}$ & 3 \\
\hline 16 & Flight delay & $\begin{array}{c}286 \\
(1.5 \%) \\
\end{array}$ & $\begin{array}{c}204 \\
(1.1 \%) \\
\end{array}$ & $\begin{array}{c}1,069 \\
(5.8 \%)\end{array}$ & $\begin{array}{c}2,394 \\
(12.9 \%) \\
\end{array}$ & $\begin{array}{c}14,614 \\
(78.7 \%)\end{array}$ & $\begin{array}{c}18,567 \\
(100.0 \%)\end{array}$ & 5 \\
\hline 17 & $\begin{array}{l}\text { Boarding } \\
\text { and }\end{array}$ & $\begin{array}{c}248 \\
(1.3 \%)\end{array}$ & $\begin{array}{c}1,298 \\
(7.0 \%)\end{array}$ & $\begin{array}{c}5,422 \\
(29.2 \%)\end{array}$ & $\begin{array}{c}7,679 \\
(41.4 \%)\end{array}$ & $\begin{array}{c}3,914 \\
(21.1 \%)\end{array}$ & $\begin{array}{c}18,561 \\
(>99.9 \%)\end{array}$ & 4 \\
\hline
\end{tabular}




\begin{tabular}{|c|c|c|c|c|c|c|c|c|}
\hline & departure & & & & & & & \\
\hline 18 & $\begin{array}{l}\text { Cabin } \\
\text { features }\end{array}$ & $\begin{array}{c}340 \\
(1.8 \%)\end{array}$ & $\begin{array}{c}1,905 \\
(10.3 \%)\end{array}$ & $\begin{array}{c}6,988 \\
(37.8 \%)\end{array}$ & $\begin{array}{c}6,891 \\
(37.1 \%)\end{array}$ & $\begin{array}{c}2,385 \\
(12.8 \%) \\
\end{array}$ & $\begin{array}{c}18,509 \\
(99.7 \%) \\
\end{array}$ & 4 \\
\hline 19 & $\begin{array}{l}\text { Seat } \\
\text { features }\end{array}$ & $\begin{array}{c}893 \\
(4.8 \%)\end{array}$ & $\begin{array}{c}3,715 \\
(20.0 \%)\end{array}$ & $\begin{array}{c}6,603 \\
(35.6 \%)\end{array}$ & $\begin{array}{c}5,205 \\
(28.0 \%)\end{array}$ & $\begin{array}{c}2,148 \\
(11.6 \%)\end{array}$ & $\begin{array}{c}18,564 \\
(>99.9 \%)\end{array}$ & 3 \\
\hline 20 & $\begin{array}{l}\text { Crew and } \\
\text { pilots }\end{array}$ & $\begin{array}{c}216 \\
(1.2 \%)\end{array}$ & $\begin{array}{c}1,001 \\
(5.4 \%)\end{array}$ & $\begin{array}{c}4,468 \\
(24.1 \%)\end{array}$ & $\begin{array}{c}7,623 \\
(41.1 \%)\end{array}$ & $\begin{array}{c}5,252 \\
(28.3 \%)\end{array}$ & $\begin{array}{c}18,560 \\
(>99.9 \%)\end{array}$ & 4 \\
\hline 21 & IFE & $\begin{array}{c}1103 \\
(6.1 \%) \\
\end{array}$ & $\begin{array}{c}3,289 \\
(18.3 \%)\end{array}$ & $\begin{array}{c}6,950 \\
(38.6 \%)\end{array}$ & $\begin{array}{c}5,069 \\
(28.2 \%)\end{array}$ & $\begin{array}{c}1,592 \\
(8.8 \%) \\
\end{array}$ & $\begin{array}{c}18,003 \\
(97.0 \%) \\
\end{array}$ & 3 \\
\hline 22 & $\begin{array}{l}\text { Inflight } \\
\text { food and } \\
\text { drink }\end{array}$ & $\begin{array}{c}535 \\
(2.9 \%)\end{array}$ & $\begin{array}{c}2,333 \\
(12.6 \%)\end{array}$ & $\begin{array}{c}6,482 \\
(34.9 \%)\end{array}$ & $\begin{array}{c}6,318 \\
(34.0 \%)\end{array}$ & $\begin{array}{c}2,834 \\
(15.3 \%)\end{array}$ & $\begin{array}{c}18,502 \\
(99.6 \%)\end{array}$ & 3 \\
\hline 23 & Arrival & $\begin{array}{c}211 \\
(1.1 \%) \\
\end{array}$ & $\begin{array}{c}1,317 \\
(7.1 \%) \\
\end{array}$ & $\begin{array}{c}6,146 \\
(33.2 \%)\end{array}$ & $\begin{array}{c}, 473 \\
(40.4 \%) \\
\end{array}$ & $\begin{array}{c}3,373 \\
(18.2 \%) \\
\end{array}$ & $\begin{array}{c}18,520 \\
(99.7 \%) \\
\end{array}$ & 4 \\
\hline $24 \mathrm{~A}$ & $\begin{array}{l}\text { Overall } \\
\text { satisfaction } \\
\text { rating }\end{array}$ & $\begin{array}{c}294 \\
(1.6 \%)\end{array}$ & $\begin{array}{c}1,314 \\
(7.1 \%)\end{array}$ & $\begin{array}{c}4,981 \\
(26.8 \%)\end{array}$ & $\begin{array}{c}8,050 \\
(43.4 \%)\end{array}$ & $\begin{array}{c}3,928 \\
(21.2 \%)\end{array}$ & $\begin{array}{c}18,567 \\
(100.0 \%)\end{array}$ & 4 \\
\hline $24 \mathrm{~V}$ & $\begin{array}{l}\text { Value for } \\
\text { money }\end{array}$ & $\begin{array}{c}298 \\
(1.6 \%) \\
\end{array}$ & $\begin{array}{c}1,640 \\
(8.8 \%) \\
\end{array}$ & $\begin{array}{c}5,825 \\
(31.4 \%) \\
\end{array}$ & $\begin{array}{c}7,316 \\
(39.4 \%) \\
\end{array}$ & $\begin{array}{c}3,488 \\
(18.8 \%) \\
\end{array}$ & $\begin{array}{c}18,567 \\
(100.0 \%) \\
\end{array}$ & 4 \\
\hline 25 & $\begin{array}{l}\text { Comparison } \\
\text { to expect. }\end{array}$ & $\begin{array}{c}434 \\
(2.3 \%)\end{array}$ & $\begin{array}{c}1,996 \\
(10.8 \%)\end{array}$ & $\begin{array}{c}10,259 \\
(55.3 \%)\end{array}$ & $\begin{array}{c}3,769 \\
(20.3 \%)\end{array}$ & $\begin{array}{c}2,109 \\
(11.4 \%)\end{array}$ & $\begin{array}{c}18,567 \\
(100.0 \%)\end{array}$ & 3 \\
\hline 26 & Loyalty & $\begin{array}{c}212 \\
(1.1 \%)\end{array}$ & $\begin{array}{c}806 \\
(4.3 \%)\end{array}$ & $\begin{array}{c}3,197 \\
(17.2 \%)\end{array}$ & $\begin{array}{c}7,474 \\
(40.3 \%)\end{array}$ & $\begin{array}{c}6,878 \\
(37.0 \%)\end{array}$ & $\begin{array}{c}18,567 \\
(100.0 \%)\end{array}$ & 4 \\
\hline 27 & Advocacy & $\begin{array}{c}300 \\
(1.6 \%)\end{array}$ & $\begin{array}{l}1,270 \\
(6.8 \%)\end{array}$ & $\begin{array}{c}4,269 \\
(23.0 \%)\end{array}$ & $\begin{array}{c}6,750 \\
(36.4 \%)\end{array}$ & $\begin{array}{c}5,978 \\
(32.2 \%)\end{array}$ & $\begin{array}{c}18,567 \\
(100.0 \%)\end{array}$ & 4 \\
\hline
\end{tabular}

The valid response rate varied by question from $83.8 \%$ to $100 \%$ for the fifteen questions. However only $5.1 \%$ of respondents answered Q9 about reservation services and $37.8 \%$ answered Q14 concerning the lounge. This may be because many respondents did not use the reservation services or lounge (for most airlines the lounge is reserved for premium class or higher-tier FFP members, whereas the largest portion of the sample travelled in Economy Class). Consequently, Q9 and Q14 were excluded from further statistical analyses because the proportion of valid responses were considered too small to represent the target population, possibly leading to biased results.

In general, the frequency distributions tended to be skewed towards the higher ends of the 5-point scales. The skewed distributions are reflected by the high median scores. The results reflect the possibility of a high level of acquiescence response bias, evidenced by the tendency of the majority (over $50 \%$ ) of the respondents to endorse, agree with, or provide positive responses (median scores of 3 to 5) for all of the questions. The instrument did not include any conflicting, contradictory, or reverse scoring questions to trap those respondents who consistently provide biased responses to questionnaires irrespective of what they really believe to be the true answer (Paulhus, 1991; Smith, 2004).

All the median scores for the ratings of different elements of the journeys were 4, Very Good, apart from 3, Good, corresponding to seat features, IFE, and inflight food and drink. The median scores for the overall satisfaction ratings of the airlines and for value for money were 4, Very Good. The median scores for loyalty, advocacy, and comparison to expectations were also 4, corresponding to Very likely to use again, Probably would recommend, and Slightly Better than expectations respectively.

Passenger satisfaction was examined against the continent of airline used, individual airline and class of travel (See Figure 2). When stratified with respect to the continent of airline flown, the median scores for the elements of the journey were uniformly 3 - Good, to 5 - Excellent. The median score for cabin features (Q18) was 3 - Good, in Europe compared to 4 - Very Good, in Asia and Middle East. The median score for IFE (Q21) was 3 - Good, in Europe and Asia compared to 4 - Very Good, in Middle East. Inflight food and drink (Q22) scored 3 - Good in Europe, compared to 4 - Very Good, in Asia and Middle East. 

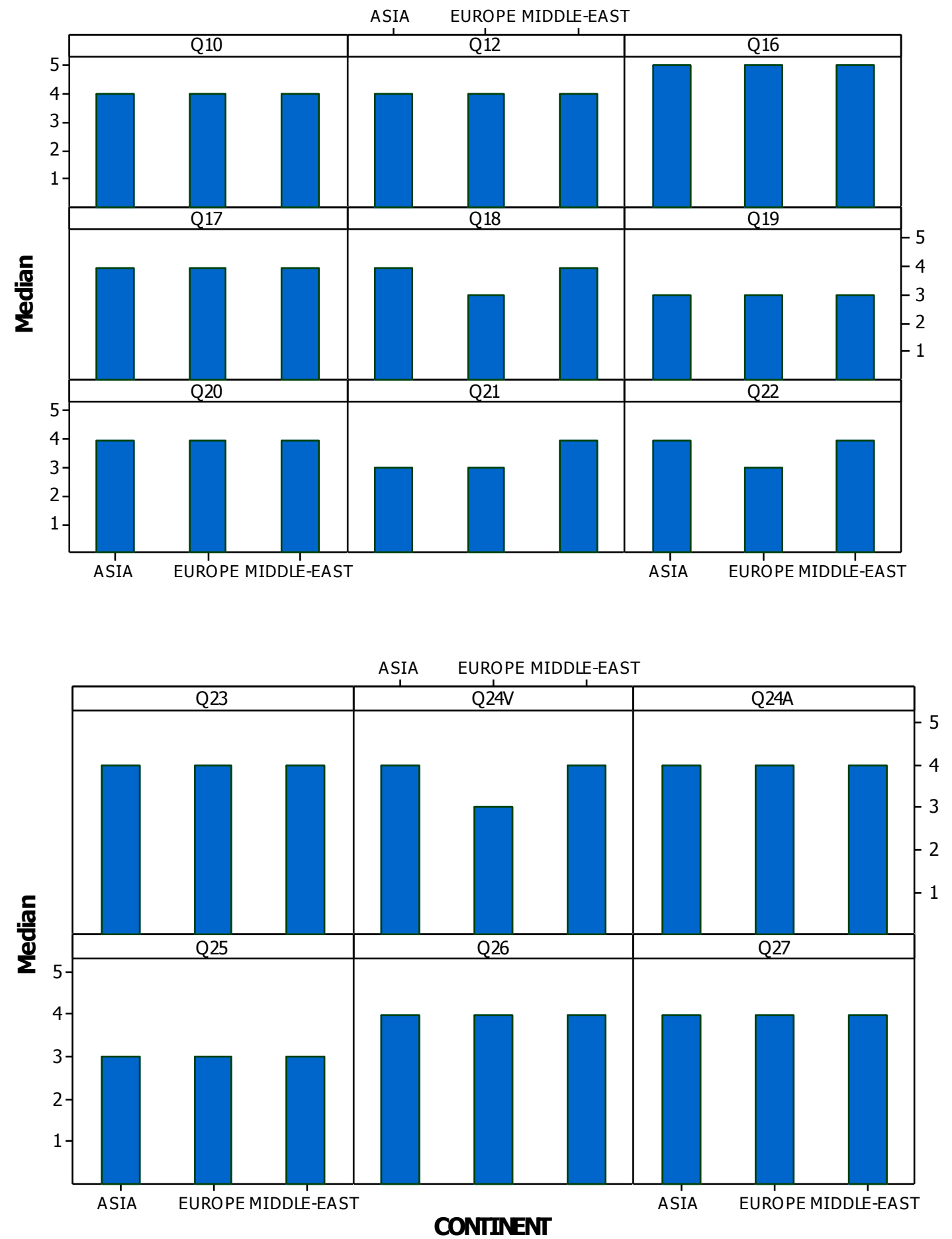

Figure 2: Distribution of Median Scores with respect to Continent of Airline

The median score for Q24 concerning value for money was 3 - Good in Europe, compared to 4 - Very Good, in Asia and Middle East. Overall satisfaction, advocacy and loyalty were 4 for all 3 categories. Comparison to expectations was stable at 3 - As Expected, for all three continents of carriers.

Airlines from Asia and the Middle East scored the same in all measures except IFE, where Middle East at 4 was rated higher than Asia at 3 . In what will be of significant concern to those airlines, European airlines were rated, comparatively, as achieving the worst passenger satisfaction, receiving equal 
lowest scores on all measures and receiving lower scores than other continent airlines on both inflight catering and value for money perceptions.

When looking at the ratings of individual airlines, there was significantly greater differentiation. The median scores varied between the fifteen airlines for ten of the questions. The median score for website (Q10) was rated as just Good for AS3 and EU1, compared to Very Good, for the other airlines. The median score for cabin features (Q18) was Good, for AS1, AS3, AS5, EU1, EU3, EU4, and EU5 compared to Very Good, for the other airlines. The median score for seat features (Q19) was Very Good, for AS2 and AS4 compared to Good, for the other airlines. The median score IFE (Q21) was Good for all airlines except AS1, AS4, ME1, and ME2, who all scored Very Good. The median score for inflight food and drink (Q22) was Good, for all airlines except AS2, AS3, AS4, EU1, ME1, ME2, and ME3, for which the median score was Very Good. Airlines EU1 and EU5 scored Good, arrival (Q23) compared to Very Good, for the other airlines. EU1, EU4, and EU5 scored Good, for value for money (Q24V), compared to Very Good, for the other airlines.

Overall "Satisfaction" was rated at Very Good, for all airlines except EU5 which was rated as Good. "Likelihood to use again" was rated Probably Would, for all airlines except AS4 who achieved a 5, Definitely Would, score. AS4 achieved the maximum rating for "Likelihood to recommend" as Extremely Likely, whereas all other airlines achieved Probably Would, except EU3, which demonstrated the lowest level of advocacy with a rating of Somewhat Likely.

AS4 appeared to deliver the strongest customer experience performance, having achieved the highest rating of all carriers. In addition to the ratings for loyalty and advocacy where they stood alone, the carrier had equal highest ratings in all other measurements. There are areas for improvement for all the carriers surveyed. It is difficult to single out a 'weakest performing' airline due to variations in performance across the measures, however the standalone low ' 3 ' scores of EU3 advocacy (Q27) and EU5 overall satisfaction (Q24A) highlight particular areas of concern for their respective airline management teams.

To test the first hypothesis, $\mathrm{H}_{0} 1$, a statistical comparison of the median scores is presented in Table 5 . The higher the values of the Kruskal-Wallis $\chi^{2}$, the greater the median score deviated from the differences as would be expected by random chance.

Table 5: Comparison of Median Scores using Kruskal-Wallis $\chi^{2}$ Tests

\begin{tabular}{llccc}
\hline Question & Rating & Continent & Airline & Class \\
\hline 10 & Website services & 2.063 & $505.642^{*}$ & $11.368^{*}$ \\
12 & Check-in & 0.77 & $411.777^{*}$ & $230.425^{*}$ \\
16 & Flight delay & $38.117^{*}$ & $248.787^{*}$ & $2.391^{*}$ \\
17 & Boarding and departure & 1.386 & $580.901^{*}$ & $32.761^{*}$ \\
18 & Cabin features & 0.343 & $1075.725^{*}$ & $469.334^{*}$ \\
19 & Seat features & 1.494 & $752.733^{*}$ & $2181.481^{*}$ \\
20 & Crew and pilots & 1.434 & $821.249^{*}$ & $302.381^{*}$ \\
21 & IFE & 0.605 & $2107.589^{*}$ & $151.154^{*}$ \\
22 & Inflight food/drink & $6.257^{*}$ & $778.271^{*}$ & $814.270^{*}$ \\
23 & Arrival & 1.161 & $518.581^{*}$ & $314.733^{*}$ \\
$24 \mathrm{~A}$ & Overall satisfaction rating & 0.341 & $982.496^{*}$ & $184.858^{*}$ \\
$24 \mathrm{~V}$ & Value for money & 0.893 & $858.262^{*}$ & $64.347^{*}$ \\
25 & Comparison to & 2.409 & $469.748^{*}$ & $29.396^{*}$ \\
26 & expectations & 0.167 & $1042.516^{*}$ & $236.264^{*}$
\end{tabular}




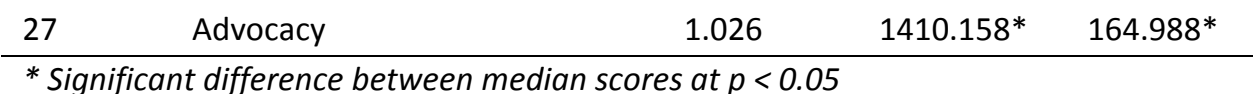

Looking, firstly at the continent of the airline used, the median scores for the ratings of flight delay and inflight food and drink varied significantly at $p<.05$. All of the median scores for the passenger ratings varied significantly at $p<.05$ with respect to the fifteen airlines and the four flight classes. These results, on prima facé basis, suggest that the both airline and flight class have impact on passenger ratings, whilst the continent of the airline is not significant. However, as indicated earlier, for large data sets, such results should be treated with circumspection.

Although the results of most of the Kruskal-Wallis tests were statistically significant at $p<.05$, the $\chi^{2}$ statistics do not indicate the magnitude of the effect of either continent, airline or flight class on the passengers' ratings. To indicate the effect sizes, a matrix of Cramer's $V$ coefficients measuring the strengths of the correlations between the passengers ratings and the continent of the airline, the individual airline, and class of flight were examined (Table 6).

Table 6: Cramer's V Correlations between Customer Satisfaction Ratings for Continent of Airline, Individual Airline and Class of Flight

\begin{tabular}{lllll}
\hline Question & Rating & Continent & Airline & Class \\
\hline 10 & Website services & 0.067 & 0.102 & 0.030 \\
12 & Check-in & 0.051 & 0.082 & 0.065 \\
16 & Flight delay & 0.036 & 0.070 & 0.016 \\
17 & Boarding and departure & 0.068 & 0.094 & 0.036 \\
18 & Cabin features & 0.123 & 0.130 & 0.098 \\
19 & Seat features & 0.104 & 0.110 & 0.077 \\
20 & Crew and pilots & 0.110 & 0.111 & 0.077 \\
21 & IFE & 0.168 & 0.200 & 0.067 \\
22 & Inflight food and drink & 0.132 & 0.110 & 0.129 \\
23 & Arrival & 0.071 & 0.109 & 0.081 \\
$24 \mathrm{~A}$ & Overall satisfaction rating & 0.129 & 0.122 & 0.061 \\
$24 \mathrm{~V}$ & Value for money & 0.131 & 0.114 & 0.040 \\
25 & Comparison to expectations & 0.112 & 0.105 & 0.036 \\
26 & Loyalty & 0.116 & 0.129 & 0.068 \\
27 & Advocacy & 0.136 & 0.147 & 0.057 \\
\hline
\end{tabular}

All of the Cramer's $V$ coefficients were statistically significant at $p<0.05$, however this does not necessarily imply a strong correlation. Nearly than half of the coefficients presented are less than 0.1 , implying little or no correlation between the satisfaction ratings of the passengers the continent of the airline, the airline, or the class of flight (see Table 2).

Very weak correlations were found between the continents of the airlines and the responses to ten of the questions. In order of magnitude, the categorical correlation coefficients reflected relationships between the continent of the airline and the ratings for IFE $(V=0.168)$, advocacy $(V=0.136)$, inflight food and drink $(V=0.132)$; value for money $(V=0.131)$; overall satisfaction rating $(V=0.129)$; cabin features $(V=0.123)$; loyalty $(V=0.116)$; crew and pilots $(V=0.110)$; comparison to expectations $(V=$ $0.112)$; and seat features $(V=0.104)$. 
In order of magnitude, the categorical correlation coefficients also reflected very weak relationships between the airlines and the ratings for IFE $(V=0.200)$; advocacy $(V=0.147)$; cabin features $(V=$ $0.130)$; loyalty $(V=0.129)$; overall satisfaction rating $(V=0.122)$; inflight food and drink $(V=0.132)$; value for money $(V=0.114)$; crew and pilots $(V=0.111)$; arrival $(V=0.109)$; and comparison to expectations $(V=0.105)$. A very weak correlation $(V=0.129)$ was found between the flight class and the level of passenger satisfaction with the inflight food and drink, with First Class and Business Class passengers rating inflight food and drink better than those travelling in Economy Class.

In conclusion, the hypothesis $\mathrm{H}_{0} 1$ was partially rejected. The analysis did reveal statistically significant relationships at $p<0.05$, however, considerations of the strength of the relationships did not identify very strong effects of these variables on the relative satisfaction levels of the passengers.

This initially disappointing result suggests that consumer experience may not be a rewarding area of study for researchers looking to make suggestions to airlines as to how to improve customer experience, loyalty or advocacy. However, that no single service item has significant impact on customer experience in respect of the continent of the airline used, the specific airline used or the class of travel used is not all together a surprising result. Here, the aggregation of the data, the large data sample, the limited range of responses, and their skewdness towards the higher response items (see Table 4), mean that strong correlations were unlikely to be identified. A wider number of response categories may have led to a more interesting conclusion to this research aim, however, as the research team were not able to define the survey instrument this was not possible.

To test $\mathrm{H}_{0} 2$ 's null hypothesis, that passengers' satisfaction ratings for specified elements of their journeys were not correlated with their rating for overall satisfaction, a matrix of Spearman's rank coefficients was prepared (Table 7). All the correlation coefficients were significant at $p<0.05$, so the null hypothesis was rejected. In other words, the findings clearly suggest that overall customer satisfaction is directly effected by the customer experience touchpoints they experience within their journey.

Table 7: Spearman's Rank Correlations between Passenger Ratings for Elements of the Journey and their Overall Satisfaction Ratings (Q24A) for the Airlines

\begin{tabular}{llllllllll}
\multicolumn{1}{c}{} & \multicolumn{1}{c}{ AIRLINE } \\
\cline { 3 - 9 } Question & Element of Journey & AS1 & AS2 & AS3 & AS4 & AS5 & EU1 & EU2 & EU3 \\
\hline 18 & Cabin features & 0.636 & 0.591 & 0.626 & 0.611 & 0.647 & 0.551 & 0.624 & 0.635 \\
20 & Crew and pilots & 0.629 & 0.598 & 0.645 & 0.597 & 0.605 & 0.615 & 0.632 & 0.636 \\
22 & Inflight food/drink & 0.610 & 0.590 & 0.603 & 0.560 & 0.561 & 0.559 & 0.594 & 0.651 \\
19 & Seat features & 0.570 & 0.538 & 0.584 & 0.518 & 0.577 & 0.532 & 0.618 & 0.585 \\
21 & IFE & 0.531 & 0.517 & 0.563 & 0.504 & 0.523 & 0.580 & 0.545 & 0.562 \\
23 & Arrival & 0.568 & 0.565 & 0.580 & 0.499 & 0.534 & 0.497 & 0.582 & 0.592 \\
17 & Boarding/Departure & 0.528 & 0.506 & 0.555 & 0.502 & 0.534 & 0.505 & 0.557 & 0.548 \\
10 & Website services & 0.494 & 0.467 & 0.465 & 0.388 & 0.441 & 0.415 & 0.447 & 0.462 \\
12 & Check-in & 0.469 & 0.412 & 0.447 & 0.386 & 0.412 & 0.344 & 0.424 & 0.415 \\
16 & Flight delays & 0.073 & 0.043 & 0.104 & 0.140 & 0.141 & 0.131 & 0.172 & 0.096 \\
\hline
\end{tabular}

\begin{tabular}{lllllllllll}
\cline { 3 - 9 } \multicolumn{10}{c}{ AIRLINE } \\
\hline Question & Element of Journey & EU4 & EU5 & EU6 & EU7 & ME1 & ME2 & ME3 & All 15 \\
\hline 18 & Cabin features & 0.668 & 0.658 & 0.626 & 0.640 & 0.640 & 0.633 & 0.624 & 0.645 \\
20 & Crew and pilots & 0.658 & 0.652 & 0.615 & 0.595 & 0.632 & 0.636 & 0.609 & 0.638 \\
22 & Inflight food/drink & 0.638 & 0.623 & 0.607 & 0.621 & 0.637 & 0.639 & 0.590 & 0.620
\end{tabular}




\begin{tabular}{llllllllll}
19 & Seat features & 0.608 & 0.625 & 0.584 & 0.598 & 0.600 & 0.607 & 0.593 & 0.598 \\
21 & IFE & 0.556 & 0.568 & 0.527 & 0.554 & 0.599 & 0.558 & 0.537 & 0.569 \\
23 & Arrival & 0.575 & 0.553 & 0.523 & 0.529 & 0.590 & 0.588 & 0.580 & 0.567 \\
17 & Boarding/Departure & 0.577 & 0.526 & 0.533 & 0.501 & 0.559 & 0.537 & 0.579 & 0.547 \\
10 & Website services & 0.544 & 0.527 & 0.442 & 0.390 & 0.471 & 0.506 & 0.424 & 0.470 \\
12 & Check-in & 0.458 & 0.419 & 0.390 & 0.394 & 0.509 & 0.485 & 0.475 & 0.437 \\
16 & Flight delays & 0.137 & 0.095 & 0.143 & 0.168 & 0.138 & 0.111 & 0.117 & 0.122 \\
\hline
\end{tabular}

The order of magnitudes of the correlation coefficients for the combined airlines was reflected by the pattern of distribution of coefficients for the individual airlines. The cabin features ratings were most strongly correlated with overall satisfaction ( $r h o=0.611$ to 0.668 ) across AS1, AS3, AS4, AS5, EU4, EU5, EU6, EU7, ME1, and ME3. The ratings for crew and pilots had the strongest correlation with overall satisfaction ( $r h o=0.598$ to 0.636 ) across AS2, EU1, EU2, EU3, and ME2. The correlations were strong ( $r$ ho $=0.603$ to 0.651 ) between the ratings for inflight food and drink and overall satisfaction across AS1, AS3, EU3, EU4, EU7, ME1, and ME2.

The ratings for the website services ( $r$ ho $=0.388$ to 0.506 ) and check-in ( $r$ ho $=0.390$ to 0.509 ) for all fifteen airlines were weakly to moderately correlated with overall satisfaction. Flight delay was very weakly correlated with the overall satisfaction ratings across all the airlines ( $r h o=0.043$ to 0.168 ). The low correlation between overall satisfaction and delays, suggests that this factor impacts satisfaction when the customer experiences a delay and not at other times, and that largely delays are not a major issue for the airlines sampled. On time performance may, therefore, be considered a hygiene factor for all airlines.

Consequently, the outcome of $\mathrm{H}_{0} 2$ suggests that airlines should focus on developing cabin features, crew and pilot personality, inflight food and drink as these items most contribute to the overall satisfaction derived by passengers.

To test $\mathrm{H}_{0} 3^{\prime} \mathrm{s}$ null hypothesis, that the satisfaction ratings for specified elements of the journeys were not correlated with loyalty ratings, the Spearman's rank correlations (Table 8) were examined. All but three of the coefficients were significant at $p<0.05$, thus the alternative hypothesis was accepted that passenger satisfaction affects customer loyalty.

Table 8: Spearman's Rank Correlations between Passenger Ratings for Elements of the Journey and their Loyalty (Q26) for the Airlines

\begin{tabular}{llllllllll}
\cline { 3 - 8 } & \multicolumn{1}{c}{ AIRLINE } & & & & & & \\
\hline Question & Element of Journey & AS1 & AS2 & AS3 & AS4 & AS5 & EU1 & EU2 & EU3 \\
\hline 18 & Cabin features & 0.399 & 0.366 & 0.470 & 0.442 & 0.463 & 0.431 & 0.368 & 0.528 \\
22 & Inflight food/drink & 0.396 & 0.385 & 0.493 & 0.401 & 0.393 & 0.374 & 0.420 & 0.452 \\
20 & Crew and pilots & 0.438 & 0.387 & 0.460 & 0.377 & 0.402 & 0.434 & 0.387 & 0.485 \\
19 & Seat features & 0.401 & 0.367 & 0.460 & 0.393 & 0.430 & 0.390 & 0.366 & 0.498 \\
21 & IFE & 0.373 & 0.305 & 0.440 & 0.390 & 0.428 & 0.411 & 0.349 & 0.445 \\
10 & Website services & 0.389 & 0.309 & 0.393 & 0.312 & 0.381 & 0.345 & 0.317 & 0.450 \\
23 & Arrival & 0.330 & 0.338 & 0.383 & 0.345 & 0.330 & 0.337 & 0.355 & 0.390 \\
17 & Boarding/Departure & 0.320 & 0.303 & 0.393 & 0.306 & 0.367 & 0.364 & 0.325 & 0.427 \\
12 & Check-in & 0.275 & 0.284 & 0.299 & 0.297 & 0.282 & 0.273 & 0.240 & 0.348 \\
16 & Flight delay & 0.029 & 0.315 & 0.022 & 0.065 & 0.116 & 0.092 & 0.127 & 0.094
\end{tabular}

Table 8: Continued 


\begin{tabular}{lllllllllll}
\cline { 3 - 3 } \multicolumn{1}{c}{ AIRLINE } \\
\cline { 3 - 10 } Question & Element of Journey & EU4 & EU5 & EU6 & EU7 & ME1 & ME2 & ME3 & All 15 \\
\hline 18 & Cabin features & 0.373 & 0.515 & 0.470 & 0.463 & 0.461 & 0.532 & 0.428 & 0.464 \\
22 & Inflight food/drink & 0.379 & 0.448 & 0.417 & 0.456 & 0.460 & 0.500 & 0.423 & 0.448 \\
20 & Crew and pilots & 0.341 & 0.506 & 0.420 & 0.457 & 0.484 & 0.506 & 0.414 & 0.447 \\
19 & Seat features & 0.410 & 0.490 & 0.448 & 0.467 & 0.468 & 0.507 & 0.422 & 0.446 \\
21 & IFE & 0.380 & 0.485 & 0.382 & 0.412 & 0.403 & 0.433 & 0.406 & 0.424 \\
10 & Website services & 0.370 & 0.393 & 0.378 & 0.346 & 0.361 & 0.448 & 0.309 & 0.375 \\
23 & Arrival & 0.287 & 0.360 & 0.309 & 0.342 & 0.409 & 0.423 & 0.390 & 0.366 \\
17 & Boarding/Departure & 0.281 & 0.349 & 0.326 & 0.319 & 0.400 & 0.419 & 0.361 & 0.353 \\
12 & Check-in & 0.306 & 0.293 & 0.278 & 0.327 & 0.328 & 0.358 & 0.336 & 0.304 \\
16 & Flight delay & 0.079 & 0.051 & 0.073 & 0.062 & 0.078 & 0.079 & 0.042 & 0.069 \\
\hline
\end{tabular}

When all the airlines were combined (denoted by 'All 15' in Table 8) the elements of the journey that were most strongly (but only moderately) correlated with loyalty were cabin features ( $r$ o $=0.464$ ); inflight food and drink ( $r h o=0.448$ ); and crew and pilots ( $r h o=0.447$ ). The ratings for seat features, IFE, website services, arrival, boarding/departure, were weakly to moderately correlated with loyalty (rho $=0.353$ to 0.446$)$.

The order of magnitudes of the correlations for the combined airlines was reflected by the pattern of distribution of coefficients for the individual airlines. The cabin features were the most highly correlated ratings with loyalty (rho $=0.431$ to 0.532 ) across AS1, AS4, AS5, EU1, EU3, EU5, EU6, EU7, ME1, ME2 and ME3. The ratings for inflight food and drink had the strongest correlation with loyalty ( $r$ o $=0.379$ to 0.493 ) across AS2, AS3, EU2, and EU4.

The ratings for crew and pilots ( $r h o=0.341$ to 0.506 ) and seat features ( $r$ ho $=0.366$ to 0.507 ) were weakly to moderately correlated with loyalty for all the airlines. The correlations between loyalty and both IFE and website services were consistently weak ( $r$ o $=0.305$ to 0.450 ) for all the airlines. Flight delay consistently had little or no correlation, or a very weak correlation, with the loyalty ratings across all of the airlines ( $r$ o $=0.022$ to 0.127 ).

The result of $\mathrm{H}_{0} 3$ are well aligned with those for $\mathrm{H}_{0} 2$. The factors that most impact passenger satisfaction are cabin features, crew and pilot performance, and inflight food and drink, and airlines that perform well on these areas are most likely to win the loyalty of their customers.

To test hypothesis $\mathrm{H}_{0} 4$, that the passengers' satisfaction ratings for specified elements of their journeys were correlated with their advocacy, correlation coefficients are presented in Table 9. All but two of the coefficients were statistically significant at $p<0.05$, so the alternative hypothesis was accepted - that passenger satisfaction affects their level of advocacy for the flown airline.

Table 9: Spearman's Rank Correlations between Passenger Ratings for Elements of the Journey and their Advocacy (Q27) for the Airlines

\begin{tabular}{llllllllll}
\cline { 3 - 9 } & \multicolumn{1}{c}{ AIRLINE } \\
\hline Question & Element of Journey & AS1 & AS2 & AS3 & AS4 & AS5 & EU1 & EU2 & EU3 \\
\hline 18 & Cabin features & 0.492 & 0.417 & 0.509 & 0.468 & 0.542 & 0.454 & 0.426 & 0.597 \\
22 & Inflight food/drink & 0.485 & 0.459 & 0.512 & 0.443 & 0.475 & 0.431 & 0.455 & 0.547 \\
20 & Crew and pilots & 0.502 & 0.461 & 0.503 & 0.481 & 0.517 & 0.522 & 0.452 & 0.555 \\
19 & Seat features & 0.471 & 0.404 & 0.480 & 0.414 & 0.477 & 0.406 & 0.415 & 0.539 \\
21 & IFE & 0.429 & 0.350 & 0.487 & 0.407 & 0.456 & 0.470 & 0.387 & 0.497 \\
23 & Arrival & 0.405 & 0.380 & 0.423 & 0.354 & 0.407 & 0.370 & 0.391 & 0.445 \\
17 & Boarding/Departure & 0.405 & 0.384 & 0.441 & 0.363 & 0.437 & 0.411 & 0.379 & 0.467
\end{tabular}




\begin{tabular}{llllllllll}
10 & Website services & 0.414 & 0.310 & 0.435 & 0.316 & 0.409 & 0.433 & 0.339 & 0.458 \\
12 & Check-in & 0.318 & 0.317 & 0.304 & 0.290 & 0.344 & 0.317 & 0.283 & 0.373 \\
16 & Flight delays & 0.058 & 0.030 & 0.107 & 0.095 & 0.095 & 0.101 & 0.119 & 0.065 \\
\hline
\end{tabular}

Table 9: Continued

\begin{tabular}{llllllllll}
\hline \multicolumn{1}{c}{ AIRLINE } & & & & & & \\
\hline Question & Element of Journey & EU4 & EU5 & EU6 & EU7 & ME1 & ME2 & ME3 & All 15 \\
\hline 18 & Cabin features & 0.480 & 0.574 & 0.509 & 0.531 & 0.515 & 0.543 & 0.487 & 0.520 \\
22 & Inflight food/drink & 0.472 & 0.529 & 0.461 & 0.527 & 0.518 & 0.534 & 0.514 & 0.511 \\
20 & Crew and pilots & 0.494 & 0.591 & 0.511 & 0.542 & 0.543 & 0.576 & 0.547 & 0.504 \\
19 & Seat features & 0.478 & 0.550 & 0.473 & 0.545 & 0.496 & 0.501 & 0.470 & 0.487 \\
21 & IFE & 0.444 & 0.532 & 0.432 & 0.447 & 0.456 & 0.465 & 0.461 & 0.468 \\
23 & Arrival & 0.382 & 0.419 & 0.344 & 0.410 & 0.445 & 0.454 & 0.466 & 0.411 \\
17 & Boarding/Departure & 0.378 & 0.377 & 0.368 & 0.385 & 0.446 & 0.440 & 0.476 & 0.409 \\
10 & Website services & 0.452 & 0.447 & 0.410 & 0.377 & 0.389 & 0.458 & 0.347 & 0.405 \\
12 & Check-in & 0.375 & 0.347 & 0.291 & 0.371 & 0.423 & 0.400 & 0.400 & 0.337 \\
16 & Flight delays & 0.078 & 0.050 & 0.069 & 0.063 & 0.094 & 0.089 & 0.077 & 0.075 \\
\hline
\end{tabular}

When all the airlines were combined by continent of origin (denoted by 'All 15' in Table 9) the elements of the journey that were most strongly (but only moderately) correlated with advocacy were, in order of magnitude, cabin features $(r h o=0.520)$; inflight food and drink ( $r h o=0.511)$; crew and pilots $(r h o=0.504)$; seat features $(r h o=0.487)$ and IFE $(r h o=0.468)$. The correlations between advocacy and the ratings for arrival, website services, boarding/departure and check in were consistently weak ( $r h o=0.290$ to 0.466 ) for all the airlines. Flight delay consistently exhibited little or no correlation, or a very weak correlation, with the advocacy ratings across all of the airlines ( $r$ o $=$ 0.030 to 0.119 ). This result suggest that passengers do not necessarily stop advocating an airline that delays them. The reasons for delays may be too diverse for passengers to directly blame their airline with a delay. This must be encouraging for airlines that suffer in markets where poor weather, or air traffic limitations may affect on time performance.

The result here on $\mathrm{H}_{0} 4$ suggests, once again, that airlines that perform well on cabin features, crew personality and performance, and inflight product will benefit. Airlines that do well in these areas earn high levels of passenger satisfaction, loyalty and advocacy.

The final hypothesis, $\mathrm{H}_{0} 5$, was to examine whether passengers' satisfaction ratings for specified elements of their journeys and their overall satisfaction, loyalty, and advocacy, were moderated by the flight class (Business Class or Economy Class) taken was tested using graphical means. Here due to low response rates for First Class and Premium Economy Class passengers, these cabins were not examined.

The null hypothesis was accepted if the two regression lines (one for Business Class and the other for Economy Class) were approximately parallel, indicating that the strength and/or direction of the relationship was similar. The null hypothesis was rejected if the two regression lines drawn on the scatterplot were clearly not parallel, or crossed, indicating that the strength and/or direction of the relationship was moderated by the flight class.

The graphs to test the null hypothesis are presented in Figure 3 (to test for moderation of overall satisfaction); Figure 4 (to test for moderation of loyalty) and Figure 5 (to test for moderation of advocacy). The gradients for the graphs Overall Satisfaction (Figure 3) and Advocacy (Figure 5) are similar, but the gradient of the graphs in Figure 4 for Loyalty are somewhat flatter. It would suggest that loyalty is somewhat more resilient to differences in service, whereas passengers will change their 
ratings for a particular flight and alter their degree of advocacy for an airline in response to a recent flight experience.

The pairs of linear regression lines in each graph are seen to be approximately parallel, with no wide divergences or clear crossings of the lines reflecting moderation by flight class. Consequently, the null hypothesis was accepted. It can be inferred from the results of the graphical analysis that the relationships between the passengers' satisfaction ratings for specified elements of their journeys, and their overall satisfaction, loyalty, and advocacy were not strongly moderated by their flight class.

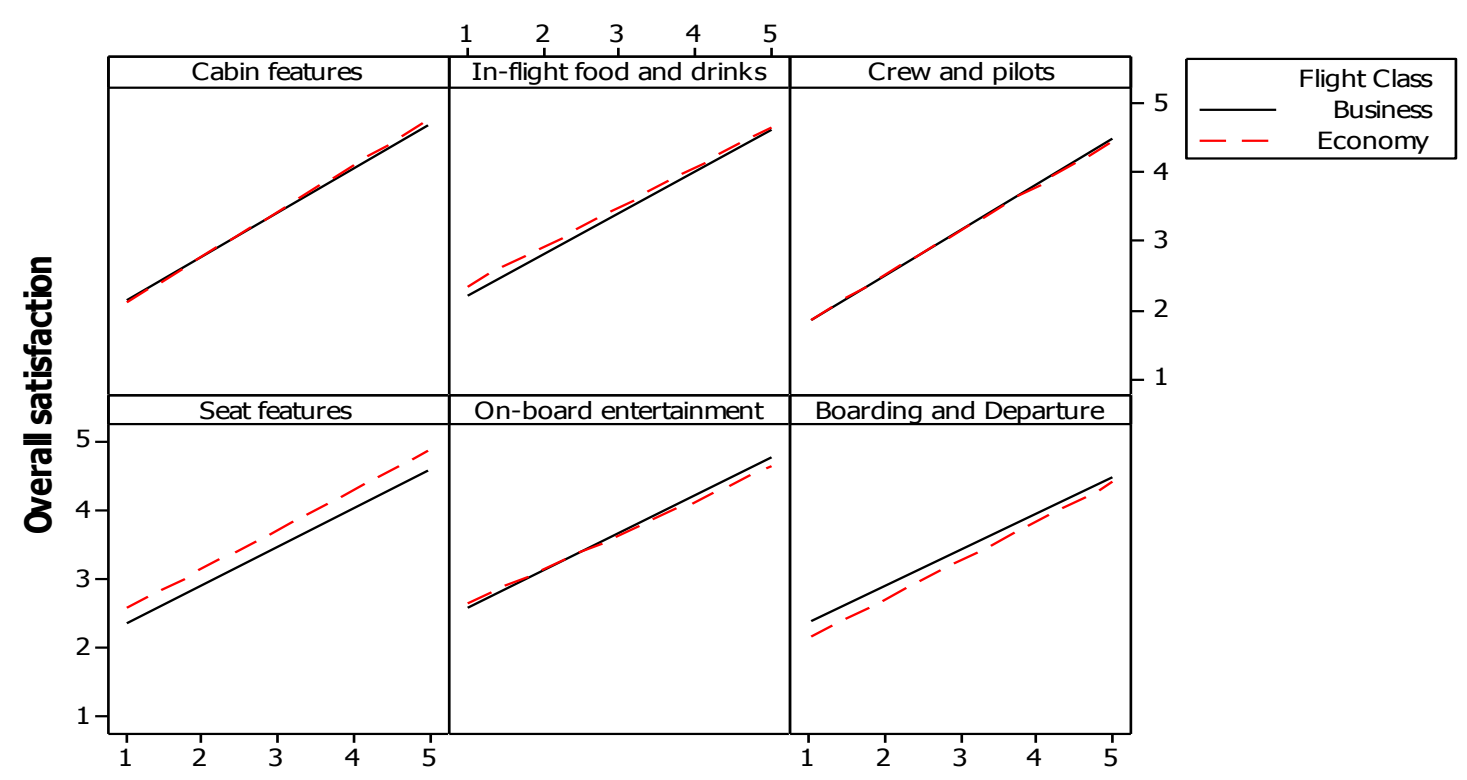

Figure 3: Graphical Analysis of the Moderation of Overall Satisfaction by Flight Class

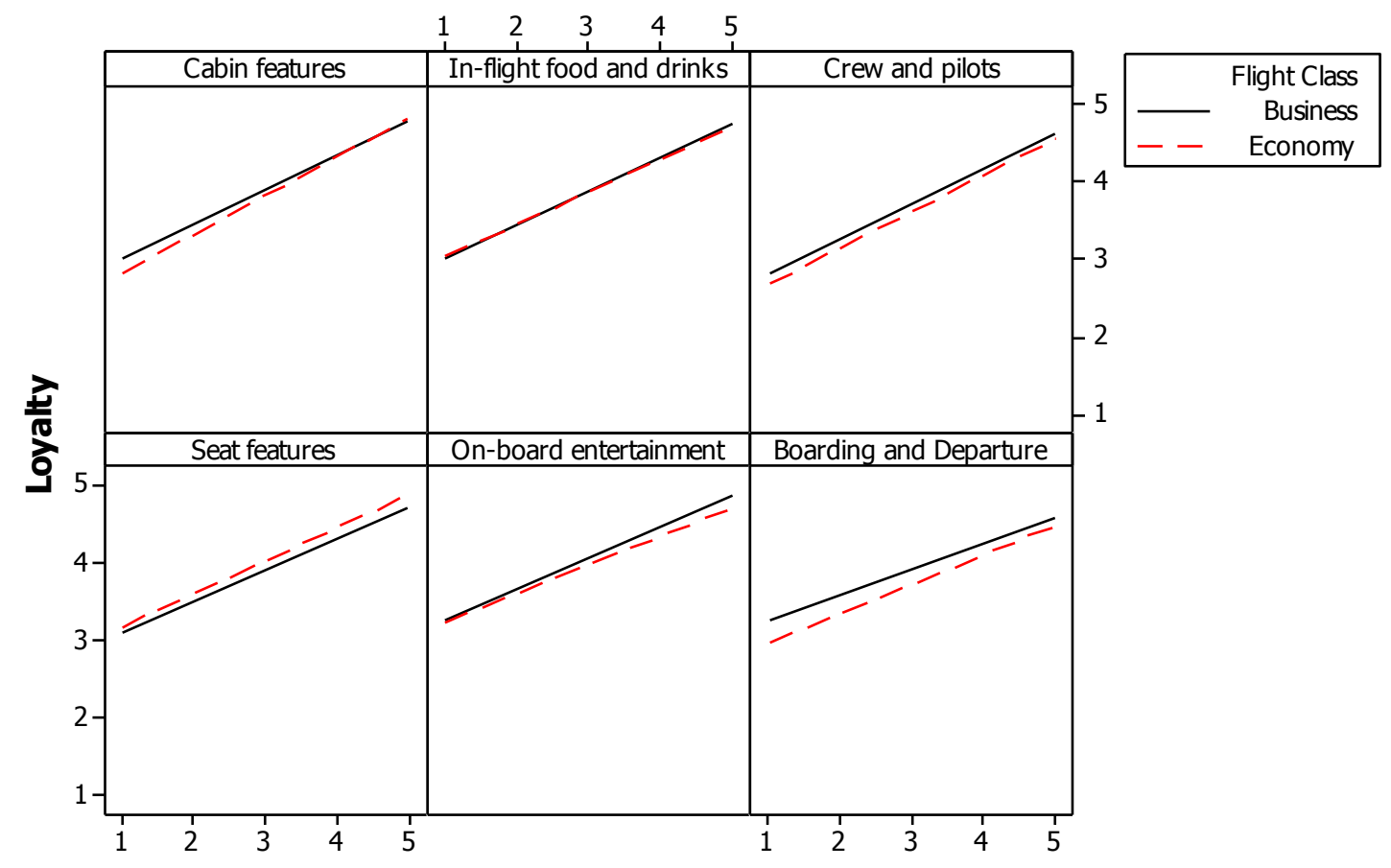

Figure 4: Graphical Analysis of the Moderation of Loyalty by Flight Class 


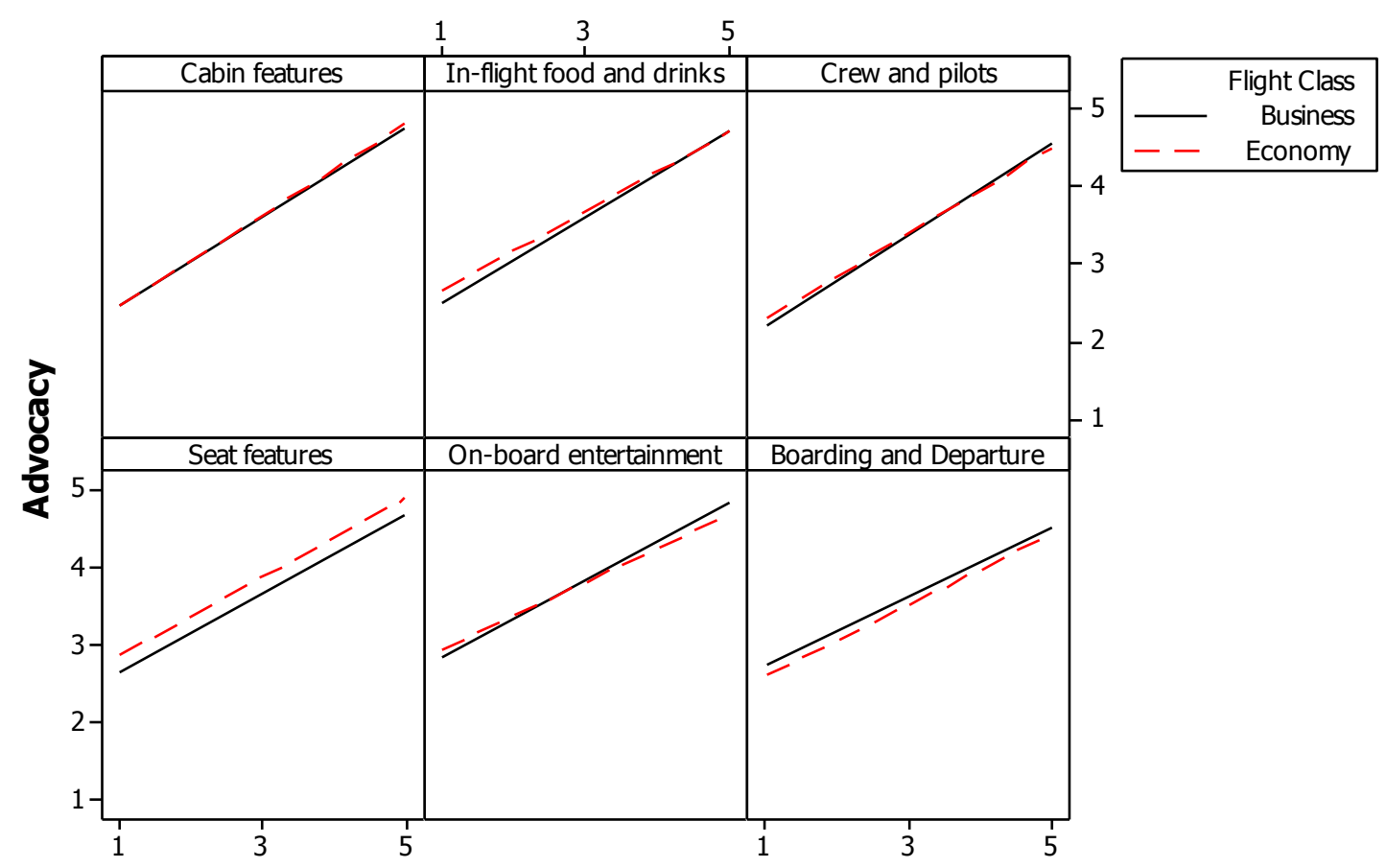

Figure 5: Graphical Analysis of the Moderation of Loyalty by Flight Class

This is an interesting result as airline managers would perhaps expect that a passenger travelling in Business Class would derive different levels of satisfactions than those travelling in Economy class. The results suggest that passengers travelling in different cabins establish their satisfactions against the level expected within each cabin. In other words, a traveller used to travelling in, say, Economy Class but upgraded and travelling in Business Class will rate their satisfaction against the levels of service expected by the traveller in that specific cabin. Satisfaction is based on expectation levels for the cabin travelled in. The results suggest that airlines must meet customer expectations in all cabins to gain deliver excellent customer satisfaction, and earn loyalty and advocacy. They cannot afford to be excellent in just one cabin.

\section{Conclusion}

The aim of this paper was to analyse the concept of customer experience, its application to the airline industry and demonstrate an understanding of how well airline brands in the current industry are performing against the customer experience measures.

The results from the survey suggests that Middle Eastern and Asian carriers were considered to be delivering a better customer experience then their European counterparts. Middle Eastern airlines delivered a higher score in IFE over Asian carriers, otherwise all measures were equal between the two continents. European carriers scored lower on all measures including IFE, cabin features, inflight food and drink and the perception of value for money. Here, clearly, these airlines need to do more to satisfy their customers.

Whilst premium cabins achieved higher scores in some measures than the Economy cabins this was limited to three measures for Business and First Classes (cabin features, seat features and inflight food and drink). First Class achieved higher scores than Business suggesting that the "First Class" experience is something considered very special. Unfortunately, insufficient data was available to test the degree to which First Class travel moderated passenger satisfaction, loyalty or advocacy. 
One airline stood out. AS4 received equal first in all measures when benchmarked versus its competitor carriers other than two measures where it outperformed all others: their median score for likelihood to use again (loyalty) and likelihood to recommend (advocacy) was 5 - the ratings 'definitely' and 'extremely likely' respectively - demonstrating an excellent delivery of customer experience.

Generally, however the first step for airlines is to gain a deeper understanding of customer experience. The validity of this concept has been demonstrated in this study as has its relevance to the airline industry. The finding that overall satisfaction is principally derived from cabin features, crew and pilot performance, and inflight food and drink, and these items drive customer loyalty and advocacy should clearly direct future airline managerial attention. Instilling the concept of customer experience into the management, structure and focus of airline brands, in order to improve the measures of customer experience for airline passengers, would enable airlines to begin to create individual defensible brand spaces.

\section{References}

Addis, M. And Holbrook, M.B. (2001) On the conceptual link between mass customisation and experiential consumption: an explosion of subjectivity. Journal of Consumer Behaviour, 1(1), pp. 50-66.

Agresti, A. (2007). Categorical Data Analysis, Second Edition. Wiley-Interscience, New York.

Baumgartner, P. (2011). An interview with Peter Baumgartner, Chief Commercial Office, Etihad Airways. Abu Dhabi. 10 ${ }^{\text {th }}$ August 2011.

Bilton, J. (2008). Beyond the Subscription: Tracking the customer journey. Unpublished report. Accessed on $17^{\text {th }}$ July 2011 via http://wessenden.com/pdf/customer_journey_report_may_08.pdf.

Bowker, D.W. and Randerson, P.F. (2007). Practical Data Analysis Workbook, Third Edition. Pearson Education, Harlow.

Bullock, M. (2009). Exploring the relationship between customer experience and advocacy. MSc Thesis. Cranfield University.

CATS (2009), Corporate Air Travel Survey, International Air Travel Association, Geneva.

Chen, F. and Chang, Y. (2005). Examining service quality from a process perspective. Journal of Air Transport Management, 11(2), pp. 79-87.

Chordiant (2008). Customer Experience Management - Cxm: Cx maturity model and benchmarking Summary report. Chordiant. Unpublished report. Accessed on $27^{\text {th }}$ August 2011 via http://www.cxmmodel.com/docs/CDT_CXMM_Summary.pdf.

Driver, J., (1999), Developments in airline marketing practice, Journal of Marketing Practice: Applied Marketing Science, Vol. 5, No. 5, pp. $134-150$.

Frow, P. And Payne, A. (2007). Towards the 'perfect' customer experience. Journal of Brand Management. 15(2), pp. 89-101.

Garg, R., Rahman, Z. And Kumar, I. (2010). Evaluating a model for analyzing methods used for measuring customer experience. Journal of Database Marketing and Customer Strategy Management, 17(2), pp. 78-90.

Gentile, C., Spiller, N., and Noci, G. (2007). How to Sustain the Customer Experience: An Overview of Experience Components that Co-create Value with the Customer. European Management Journal, 25(5), pp. 395-410. 
Gilbert, D. and Wong, R.K.C. (2003). Passenger expectations and airline services: a Hong Kong based study. Tourism Management, 24, pp. 519-532.

Headley, D.E. and Bowen, B.D. (1997). International Airline Quality Measurement. Journal of Air Transportation World Wide, 2(1), pp. 55-63.

Heskett, J.L., Jones, T.O., Loveman, G.W., Sasser, W.E. and Schlesinger, L.A. (1997). The Service Profit Chain. The Free Press, New York.

Hogan, J. (2011). Guest Experience. Etihad Airways. Internal corporate communications email. Sent on $30^{\text {th }}$ May 2011.

IATA (2011). Airs@t survey of airline passengers. International Air Transport Association, Geneva, Switzerland.

IBM. (2005). Creating a 20/20 customer experience: From customers to advocates. Accessed on $14^{\text {th }}$ July 2011 via http://www-935.ibm.com/services/us/imc/pdf/g510-6472-creating-20-20-customerexperience.pdf.

Johnston, R. and Kong, X. (2011). The customer experience: a road-map for improvement. Managing Service Quality. 21(1), pp. 5-24.

Kamaladevi, B. (2010). Customer Experience Management in Retailing. Business Intelligence Journal, 3(1), pp. 37-54.

Kim, A., Cha, J., Knutson, B.J. and Beck, J.A. (2011). Development and testing of the Customer Experience Index (CEI)". Managing Service Quality, 21(2), pp. 112-125.

Klaus, P. and Maklan, S. (2007). The role of brands in a service-dominated world. Journal of Brand Management, 15(2), pp. 115-122.

Liou, J.J.H., Hsu, C., Yeh, W. and Lin, R. (2011). Using a modified grey relation method for improving airline service quality. Tourism Management, 32(6), pp. 1381-1388.

Martín, J.C., Román, C. and Espino, R. (2008). Willing to Pay for Airline Service Quality. Transport Reviews, 28(2), pp. 199-217.

Mascarenhas, O.A., Kesavan, R. and Bernacchi, M. (2006). Lasting customer loyalty: a total customer experience approach. Journal of Consumer Marketing, 23(7), pp. 397-405.

Meyer, C. And Schwager, A (2007). Understanding Customer Experience. Harvard Business Review, February, pp. 117-126.

Nadiri, H., Hussain, K., Ekiz, E.H. and Erdoğan, Ş. (2008). An investigation on the factors influencing passengers' loyalty in the North Cyprus national airline. The Total Quality Management Journal, 20(3), pp. 265-280.

Nigam, S. (2008). Six steps to building a swashbuckling airline brand. The Red Paper Series. Airline Brand Index. Unpublished report. Accessed on $11^{\text {th }}$ August 2011 via http:// www.acaassoc.com/resources/6_steps_to_building_a_swashbuckling_airline_brand.pdf.

Ostrowski, P.L., O’Brien, T.V. and Gordon, G.L. (1993). Service Quality and Customer Loyalty in the Commercial Airline Industry. Journal of Travel Research, 32(2), pp. 16-24.

Park, J., Robertson, R. and Wu, C. (2004). The effect of airline service quality on passengers' behavioural intentions: a Korean case study. Journal of Air Transport Management, 10(6), pp. 435-439. 
Paulhus, D.L. (1991). Measurement and control of response bias. In: Robinson, J.P., Shaver, P.R. and Wrightmann, L.S. (Editors). Measures of Personality and Social Psychological Attitudes, pp. 17-59. Academic Press, San Diego.

Pine, B.J. and Gilmore, J.H. (1998). Welcome to the Experience Economy. Harvard Business Review, July-August, pp. 97-105.

Rhoades, D.L. and Waguespack, B. (2005). Strategic imperatives and the pursuit of quality in the airline industry. Managing Service Quality, 15(4), pp. 344-356.

Ryder, I. (2007). Customer Experience. Journal of Brand Management, 15(2), pp. 85-88.

Shave, L. (2011). An interview with Lee Shave, Vice President - Guest Experience, Etihad Airways. Abu Dhabi. $22^{\text {nd }}$ August 2011.

Shaw, C. and Ivens, J. (2002). Building Great Customer Experiences. Palgrave Macmillan, Basingstoke.

Schmitt, B.H. (2003). Customer experience management: a revolutionary approach to connecting with your customers. John Wiley \& Sons, Hoboken.

Schuler, R., Marsella, A. and Howlett, N. (2005). 20:20 Customer Experience. Forget CRM - Long Live the Customer. IBM. Unpublished report. Accessed on $2^{\text {nd }}$ August 2011 via http://www935.ibm.com/services/de/bcs/pdf/2006/20-20-customer-experience.pdf.

Smith, P.B. (2004). Acquiescent Response Bias as an Aspect of Cultural Communication Style. Journal of Cross-Cultural Psychology, 35(1), pp. 50-61.

Smith, S and Wheeler, J, (2002), Managing the Customer Experience: Turning customers into advocates, Person, London

Springer, T., Azzarello, D. And Melton, J. (2011). What it takes to win with customer experience. Bain \& Company. Unpublished report. Accessed on 30 ${ }^{\text {th }}$ August 2011 via http://www.bain.com/Images/BB_What_it_takes_to_win_in_customer_experience.pdf.

Stewart, T.A. (1997). A satisfied customer isn't enough. Fortune, 136(2), pp. 112-113.

Strombeck, S.D. and Wakefield, K.L. (2008). Situational influences on service quality evaluations. Journal of Services Marketing, 22(5), pp. 409-419.

Temkin, B.D. (2008). The Customer Experience Journey. Forrester Research (unpublished report). Accessed on $29^{\text {th }}$ August 2011 via http://www.adobe.com/enterprise/pdfs/customer-experiencejourney.pdf.

Temkin, B. (2008a). The 6 Laws of Customer Experience. Customer Experience Matters, Unpublished Report. Accessed on 30 ${ }^{\text {th }}$ August 2011 via http://www. rightnow.com/files/whitepapers/6-Laws-ofCustomer-Experience-White-Papers.pdf.

Thompson, B. (2006). Customer Experience Management: The Value of "Moments of Truth" Part 1. Unpublished $\quad$ report. Accessed on $27^{\text {th }}$ August 2011 via http://retaintogain.com/pdf/customer_exp1.pdf.

Thompson, E. and Davies, J. (2008). Customer Experience Management: Raising Customer Satisfaction, Loyalty and Advocacy. Gartner. Unpublished report. Accessed on $15^{\text {th }}$ July 2011 via http://www.gartner.com/it/content/776100/776114/3dec08_customerexperiencewebinar.pdf. 
Verhoef, P.D., Lemon, K.N., Parasuraman, A., Roggeveen, A., Tsiros, M. and Schlesinger, L.A. (2009). Customer Experience Creation: Determinants, Dynamincs and Management Strategies. Journal of Retailing, 85 (1), pp. 31-41.

Waguespack, B., Rhoades, D.L. and Tiernan, S. (2007). An Investigation into Airline Service Quality Performance between US Legacy Carriers and their EU Competitors and Partners. Journal of Air Transportation, 12(2), pp. 59-71.

WATS (2013), The World of Air Transport Services, Vol. 57, International Air Transport Association, Geneva.

Zins, A.H. (2001). Relative attitudes and commitment in customer loyalty models: Some experiences in the commercial airline industry. International Journal of Service Industry Management, 12(3), pp. 269-294. 
2014-06-06

\section{pÿCustomer Experience an analysis of the concept and its performance in airline brands}

\section{Laming, Calum}

\section{Elsevier}

pÿLaming C, Mason K. (2014) Customer Experience an analysis of the concept and its performance in airline brands. Research in Transportation Business and Management, Volume 10, April 2014, pp.15-25

https://doi.org/10.1016/j.rtbm.2014.05.004

Downloaded from Cranfield Library Services E-Repository 